Andrea Roxana BELLOT

URV University

Tarragona, Spain

andrearoxana.bellot@urv.cat

\title{
KEEPING THE MEMORIES OF THE MALVINAS/FALKLANDS WAR ALIVE: EXPLORING MEMORIAL SITES IN THE UK, ARGENTINA AND THE FALKLAND ISLANDS
}

\begin{abstract}
Recommended Citation: Bellot, Andrea Roxana. "Keeping the Memories of the Malvinas/Falklands War Alive: Exploring Memorial Sites in the UK, Argentina and the Falkland Islands." Metacritic Journal for Comparative Studies and Theory 7.1 (2021): https://doi.org/10.24193/mjcst.2021.11.07
\end{abstract}

\begin{abstract}
The remembrance of war and commemoration practices shape the collective memories of society and, as such, war has been one of the most productive topics in memory studies. Commemorating past wars is one of the ways of constructing a commonly shared memory that would enhance group cohesion and shape collective identity. This paper will provide three examples of sites of memory in reference to the Malvinas/Falklands War, one from each side of the dispute- United Kingdom, Argentina and a third example from the actual territory of the Falkland Islands to illustrate how war memorials are an expression of patriotism, built to frame the deaths in terms of a national narrative of glorious sacrifice for cause and nation. Therefore, war commemoration recalls past experiences of suffering, but at the same time, of resistance.
\end{abstract}

Keywords: Malvinas/Falklands War; war and remembrance; collective memory; national identity; memorial sites; war monuments.

\section{Introduction}

War has been one of the most productive topics in memory studies (Ashplant et at., 2000). Commemorating the past wars of a society is one of the ways of securing a commonly shared memory that would enhance group cohesion. War commemorations have been studied "as an attempt at mourning and an effort to repair the psychological and physical damage of war" (Misztal 128). Various commemorative practices are used 
to assign symbolic meaning to the past; an idealized lost past can be recreated through acts of remembrance, but not without the risks of glorification. As King suggests, "memory can create the illusion of a momentary return to a lost past [to] articulate the complex relationship between past, present and future in human consciousness" $(2000,11)$. War and public memory have been deeply studied in the last century, as well as the process by which the language of mourning has found its way into art. ${ }^{1}$ War commemoration recalls past experiences of suffering, but at the same time, of resistance. That is why mnemonic battles, such as the battle of Goose Green in the Malvinas/Falklands War, occupy a central position in the narratives of war recollection. Past wars are remembered in commemorative practices, war memorials and monuments, and also in artistic representations of war-sculpture, painting, music, literature, and drama.

This paper aims to explore the creation of collective memories through acts of remembrance and mourning by analysing the symbolism of sites of remembrance, such as war memorials, monuments, graveyards, and museums dedicated to the Malvinas/Falklands War (UK-Argentina, 1982). In order to do so, the paper will discuss the following three examples from the parts involved in the conflict: (1) The Statue of the "Yomper." the British Falklands War Soldier, placed outside the Royal Marines Museum in Portsmouth, England; (2) the Malvinas Museum in Buenos Aires, Argentina; and (3) Darwin Cemetery in the Falkland Islands. Moreover, this paper will try to reflect on the symbolic value attached to memorial sites and collective mourning, and how the heroic dead are built into a narrative of national heroism.

\section{Acts of Remembrance and the Formation of Collective Memory}

Memory and identity formation are closely linked, since "memory is intimately connected to the way we constitute our selves" (Coker and Yeung 293). Memory interpolates both individual identity and collective national identity. Maurice Halbwachs (1999 [1950]) was the first to introduce the concept of collective memory. Halbwachs was the most important figure within Durkheimian sociology in the interwar period. Like Émile Durkheim, Halbwachs was of the idea that every society needs, and shows, continuity with the past. Both thinkers emphasize the collective

\footnotetext{
${ }^{1}$ Some of the main research on war, memory and art has been carried out by Fussell 1975, Mosse 1990, Winter 1995, Evans and Lunn 1997, Peitsch, Burdett and Gorrara 1999, Ashplant, Dawson and Roper 2000, Erll and Nünning 2008, among many others.
} 
nature of social consciousness and that a collectively imagined past is crucial for a society to become united and successful. Halbwachs also agrees with Durkheim in that the "function of remembering is not to transform the past but to promote a commitment to the group by symbolising its values and aspirations" (Misztal 51). This notion of collective memory without altering the past is challenged by later conceptions. Halbwachs differs from Durkheim in that the former expands on the idea of collective memory as being a mechanism that all societies use, not only the most traditional ones. For Halbwachs, collective memory works on, and in, any social group, and it involves a process by which the past events of a community are shaped and transformed in such a way that those past experiences of the group are meaningful for the construction of societal identities and values of today. In other words, collective memory is socially framed in the sense that every society decides what should be remembered and how to put this into practice. This last aspect links historical memory to power, as it is normally those who hold power in a society who decide the 'what' and the 'how' of the process of remembering. Halbwachs was a pioneer in the study of social memory, however, his notions of the connection between past and present are questioned for being one dimensional and presuming a vision of frozen social identity.

The 'presentist' memory approach, also called the 'invention of tradition perspective' or 'the theory of the politics of memory', offers another perspective, as it is believed that public rituals are modes of social control. The 'presentists' argue that the past is moulded to serve the present needs of the dominant classes, and they examine the manipulation of public notions of history through war commemorations, education, mass media, and official calendars. As Barbara Misztal contends, research following the 'invention of tradition' approach has shown "how nationalist movements create a master commemorative narrative that highlights their members' common past and legitimizes their aspiration for a shared destiny" (56). The landmark book within this categorization of the study of memory is The Invention of Tradition (1983), edited by Eric Hobsbawm and Terence Ranger. The book describes some constructed war commemorations and rituals which were designed by modern states with the intention of promoting social cohesion, legitimizing authority and/or constructing a shared culture. Researchers in this area point out to the promoters of social memories and how these newly invented traditions serve those in power, which is why they pay special attention to the role of the dominant narratives (top-down approach). Critics of this perspective question the issue of the imposition of fabricated traditions in 
democratic societies and that "the memory of a social group cannot always be reduced to the political aim of sustaining relations of power" (61).

A third approach to collective memory is the so-called 'popular memory approach', also known as 'public memory', 'counter-memory', 'oppositional memory' or 'unofficial memory'. The followers of this approach argue that the construction of memory can follow a bottom-up direction. This implies that different social groups can hold their own perspective of the past. This conception of memory sprang from Foucault's ideas on memory and from the work of the British cultural studies theorists, who created the Popular Memory Group at the Centre for Contemporary Studies in Birmingham in the 1980s. Foucault (1979) conceptualizes memory as discursive practice. He believes in the possibility of popular memory (the memory of the minorities) resisting and challenging dominant memory, the one imposed by the powerful classes. New research in public memory has shown that it can be both multivocal and hegemonic. Moreover, and as Misztal suggests, "studies of counter-memory illustrate that collective memory constructed from bottom up can exist in different relations to the dominant/official representation of the past, ranging from sharp contrast to close sharp similarity" (66). Critical voices to this approach claim that the past is still being used for political reasons, and that it is made and remade in the service of new power arrangements (Schwartz quoted in Misztal, 67).

A fourth category is the 'dynamics of memory' approach. This perspective adopts a more dynamic view in the sense that collective memory is a process of ongoing negotiations. This implies that the past is not fixed; it is always in the process of construction by the narrations in the present. Barry Schwartz provides a concise definition of collective memory widely used in the field: "Collective memory is a metaphor that formulates society's retention and loss of information about its past in the familiar terms of individual remembering and forgetting" (quoted in Edy 1999, 72). Schwartz believes that an essential process in the formation of collective memory is the contrast between retention/remembering and loss/forgetting. These processes usually occur with a hidden intention. Events that contribute to the formation of the national body of a society are usually recalled repeatedly in the present, such as successful battles or heroic events that set the foundation for the nation. Schwartz adds that collective memory is "a representation of the past embodied in both historical evidence and commemorative symbolism" (quoted in Misztal, 72). For Jill Edy, past, present, and future are linked into collective memory, which she defines as the 
meaning that the community makes of its common past. She believes that "[collective memory] informs our understanding of past events and present relationships, and it contributes to our expectations about the future" $(1999,71)$.

\section{Monuments and War Commemoration}

Societies build their national narratives around the heroic dead. In Urban Gothic of the Second World War: Dark London (2010), Sara Wasson reflects on the national value of British cenotaphs (cenotaph literally means empty tomb) and the Tombs of the Unknown Warriors. The most famous in Britain are located in London: the 'Cenotaph' at Whitehall2 and the 'Tomb of the Unknown Warrior'3 at Westminster Abbey. Both memorials were built after the First World War. Wasson argues that such memorials recuperate war deaths into narratives of national glory. The Tomb of the Unknown Warrior has evoked even more reverence as both war memorial and a literal grave for one anonymous soldier. The marble slab reads that he died "for king and country, for loved ones, home and Empire.” These war memorials are an expression of patriotism, and they were built to frame the deaths in terms of a national narrative of glorious sacrifice for cause and nation. Wasson contends that the massive public participation was motivated more by personal grief than by abstract patriotism, the Unknown Warrior taken metonymically and sometimes literally to be a family's lost son/father/husband.

As previously mentioned, this paper will provide three examples of monuments from the Malvinas/Falklands War. By monumental commemoration is understood classic war memorials, sculptures and statues, museums and installations, gravestones and graveyards, and battle-sites. Robert Musil (2006) theorised about the invisibility of monuments - the majority of monuments blend into the city landscape, becoming unnoticed most of the year, except when it comes to commemorative celebrations on the spot. Even when single monuments have little visibility on the day-to-day lives of most people, acts of remembrance and commemoration practices can convey therapeutic value due to their power to heal open wounds and bring about closure.

\footnotetext{
2 For pictures and more information on this monument, please see: "What is the Cenotaph?," Imperial War Museum official website: https://www.iwm.org.uk/history/what-is-the-cenotaph (accessed in March 2021).

3 For pictures and more information on this monument, please see: "Unknown Warrior," Westminster Abbey official webpage:

https://www.westminster-abbey.org/abbey-commemorations/commemorations/unknown-warrior (accessed in March 2021).
} 
Commemoration leads to reconstruction and reconciliation since it may "enable people simultaneously to continue to remember and to feel able to move on" (Gilbert et al 3). Soldiers and family members can mourn the lives lost and the injuries suffered by those known individuals who engaged in warfare. Yet, national acts of remembrance can also generate controversy and polarization, "remembrance is a double-edged sword [...] It is dangerous, too, to not remember enough, and thus disable the remembrance process that is necessary to the formation of moral and ethical judgments and 'good' or 'just' acts" (Coker and Yeung 296). In the same vein, French cultural historian Pierre Nora (1989) argues that memory sites, which he called 'lieux de mémoire' [places of memory], can be problematic since they are loaded with symbolic meaning that can be manipulated by the government, or heritage associations, to shape the collective memory of any given nation. Niall Munro (2020) explains how a monument can serve to remind -or warn- us of great men, great victories, great sacrifices: "in this sense the monument imposes a certain point-of-view that brooks no dissent - there it stands in stone and metal, unequivocal" (115). In any case, the act of commemorating, with its atemporal features of involving the nation's past, the present and future of the community, requires an active mental exercise: it is "a flashpoint for grievances as well as a focus of reflection [...], engaging with it requires sensitivity, empathy and patience, as well as rigorous thought" (Gilbert et al. 10).

In opposition to individual mourning, societal mourning or large-group mourning takes place when people living in the same society suffer a similar experience in the way they have lost their loved ones, so they share the mourning process which then becomes collective. Monuments and dedicated cemeteries to war heroes, like for example the Darwin Cemetery on the Malvinas/Falkland Islands, are not only a place for individual grief and mourning, but also a site for collective societal mourning. Vamik Volkan reflects on the role of memorials, monuments, graveyards or any other types of memory sites in societal mourning:

By building a monument, societies create an externalized location that becomes involved in the shared mourning process [...]. Sometimes a monument as a shared linking object externally absorbed unfinished elements of incomplete mourning and helps the group to adjust to its current situation without re-experiencing the impact of the past trauma and its disturbing emotions. The marble or the metal structure suggests a sense of indestructibility. This makes the monument a psychological container in 
which the remaining unpleasant feelings of a society's shared mourning can be sealed $(2007,105)$.

At this point, it is worth pointing out the gender issues in connection with war commemoration, since war widows and mothers are leading figures in war ceremonies. Their purpose and/or 'obligation' is to serve both family and nation: they signify the sacrifice of their dead husbands or sons for the so-called 'honour' of the nation. According to Sarah Chambers (2010), the national memories of war are gendered: "brave, masculine heroes shed their blood [for the nation], while the memory of their deeds would live on through their widows and mothers" (344). Chambers adds that these women deserve public recognition as they are the bearers of the memory of the brave. That is why commemorative events related to wars, such as religious services or ceremonies, are also marked by gender divisions and gender roles: the dead heroes' mothers or widows have a leading role in the services. As Kurt Piehler explains,

The commemoration of the fallen serves to exemplify the willingness of males to serve and die for their country. [...] The role granted to women in commemorating past wars rests on the premise that combat remains a masculine endeavour. Most women during the conflict had encouraged men to fight while they kept the home fires burning. When the war ends, women ensure that their sons, husbands and ancestors will be mourned and remembered (1994, 169-170).

Likewise, Jay Winter believes that women are at centre in acts of remembrance since war affects every corner of civilian life and has a deep implication in the whole family $(2006,6)$. Men, women, and children are all victims of war because they have all experienced and witnessed war to a certain extent. That is why the memories of war are owned by men (veterans, dead heroes) and women (helpers, widows) alike.

Patriarchal discourse in times of war and post-war divides men and women into polarized gendered roles. Men embody the traditional attributes of masculinity, such as bravery and physical strength to fight in battles. War has traditionally been constructed as a masculine domain, promoting references to masculinity with a glorification of violence in the name and honour of one's country. The discourse of war is therefore highly gendered, marking a sharp division in the different roles the sexes play: men go to battle while women stay at home caring for the home and the family. 
Exercising masculinity by dying in war has often been considered as a duty, sometimes even a privilege, of male citizenship in many societies. In "Selfhood, War and Masculinity" Genevieve Lloyd (1987) explores the connection between war and gender in Western society. She argues that sacrificing one's life in battle is a sign of masculinity. Women, in turn, stay at home to prove that they are good caring mothers or spouses, ready to provide support to the returning soldiers, the healers who stay at home taking care of the family, producing more offspring for the nation, and mourning the dead.

\section{Malvinas/Falklands War Memorial Sites}

The Malvinas/Falklands War (1982) was a brief military conflict between the United Kingdom and Argentina over the sovereignty of the Malvinas/Falkland Islands. These South Atlantic islands have been part of the British overseas territory since 1833, but Argentina has always alleged that the archipelago belongs to its own national territory. Although it was a brief war of only 74 days, 2 April-14 June 1982, which resulted in relatively few casualties and losses given the size of the respective military forces involved (255 British, 649 Argentine and 3 civilian Islanders lost their lives), it stands as a blow to the collective memory of both nations and a major setback for hundreds of injured and traumatised veterans. For the UK, it was the last war over an overseas territory, and it allowed prime minister Margaret Thatcher to retain power for almost a decade after the British victory. For Argentina, it was the only war fought and lost in the 2oth century. The Argentine defeat hastened the fall of the dictatorship, which had seized power in 1976, and motivated the return of democracy in 1983. At present, nearly four decades after the end of the armed dispute, the Malvinas/Falkland Islands remain the source of a sovereignty conflict between the two countries. Argentina maintains a peaceful claim based on the notion of territorial integrity, while Britain focuses on the islanders' wishes and vigorously proclaims its commitment to defend them against any aggression.4 This paper will now provide two examples of sites of memory, in reference to the Malvinas/Falklands War, one from each side of the

\footnotetext{
4 This is shown by the continuous presence of a combined naval, air force and army deployment on the islands. Britain has always insisted that the power to decide should be given to the local inhabitants. A referendum was held on the islands in March 2013 asking the Falklanders if they wished to remain British. As expected, 99.8\% voted 'yes' (Milmo, 2013). The government of Argentina gave no credibility to this referendum and assigns no legal value to it.
} 
dispute- United Kingdom, Argentina and the third example is from the actual territory of the Falkland Islands.

\section{(1) Statue of the "Yomper": Portsmouth, England}

An iconic figure which repeatedly appears and represents the British soldiers in the Falklands War: the 'Yomper'. The image derives from an original picture taken from behind showing a group of Royal Marines marching in the frozen fields of the Islands after the British victory was announced. The Union Jack hangs on the backpack of the last marine, who later on becomes the prototypical figure for the soldier of the Falklands War. The original photograph, which was spontaneous, was taken by the Commando Forces Photographer, Officer Peter Holdgate in June 1982 when the Royal Marines yomped along Moody Brook track towards Port Stanley. The identity of the soldier remained anonymous for many years, until 2007 when it was finally known that the Yomper was the then 24-year-old Corporal Peter Robinson (Rees; NewtonDunn, 2007). Robinson placed the Union Flag on his backpack when he heard about the surrender of the Argentine forces. 'Yomp', which is an acronym for Your Own Marching Pace, is a slang term used by the Royal Marines that describes a fully equipped long-distance march. The British equivalent is 'tab', which stands for Tactical Advance Battle. A statue of the 'Yomper' adorns the entrance of the Royal Marines Museum in Portsmouth. 5 The sculpture was unveiled by Margaret Thatcher in 1992 for the tenth anniversary of the conflict. Lucy Noakes believes that the statue stands as a symbol of the gendering of warfare, since "in its physical appearance the 'Yomper' is a very active, heroic, masculine representation of war and of soldiering” (1996, 1). She adds: "Facing forwards and looking into the distance, the 'Yomper' symbolises determination and courage in wartime; both of the nation and of the individual combat” (1998, 103).

\section{(2) Malvinas Museum: Buenos Aires, Argentina}

\footnotetext{
5 For pictures and more information on this statue, please visit: "Royal Marines Museum - The Yomper," Memorials \& Monuments in Portsmouth: http://www.memorialsinportsmouth.co.uk/rmmuseum/yomper.htm (accessed in March 2021).
} 
The Malvinas Museum ${ }^{6}$ was inaugurated on 10 June 2014, a day that coincides with the commemoration of the affirmation of the Argentine rights over the territory of the Malvinas Islands ("Día de la Afirmación de los Derechos Argentinos sobre Malvinas, Islas y Sector Antártico"), by the then President Cristina Fernández de Kirchner. The museum is public, it was created by the Argentine government and it is run by the Ministry of Culture. Located in the capital city of Buenos Aires, it is set in a symbolic place, in the "Space of Memory and Human Rights." which used to be a Navy School that functioned as a clandestine centre for illegal detention and torture during the military regime of 1973-1983. The museum is dedicated to the Islas Malvinas (Falkland Islands) exclusively, and its main objective is to revendicate Argentina's claim of sovereignty over the Islands as stated in the National Constitution. The history and geography of the islands are explored in an introductory film on a 360-degree cinema screen, interactive exhibits, and innovative displays. The museum is divided into four thematic areas. The first part, titled "What's in Malvinas?" shows the geographical arguments of sovereignty, including the descriptions of the flora and fauna of the Malvinas, their geopolitical importance as well as the natural resources (renewable and non-renewable) to be found in the surrounding sea in the South Atlantic. The second area, "Why are the Falklands Argentine?," explores the historical and legal arguments of sovereignty. It begins with the colonial period (1494-1810), followed by the Argentine administrations in Malvinas (1810-1832). This section also explains the long-term claim to sovereignty from British occupation in 1833 until the $1982 \mathrm{war}$. The third section, "The Malvinas War," comprises a detailed account of the war, including an exhibition which holds objects donated by combatants that seek to reflect the poor conditions in which they lived through the battle. The last thematic area, "Post-war and Democracy," narrates the years after the war, the restauration of democracy in the country, it explains the elaboration of the Rattenbach Report (which was hidden during the dictatorship and declassified in 2012), as well as the vicissitudes of the veterans, who went into oblivion for many years. The tour comes to an end with a reflection of the current situation regarding the ongoing sovereignty claim.

\section{(3) Darwin Cemetery: Falkland Islands}

\footnotetext{
${ }^{6}$ The full name in Spanish is "Museo Malvinas e Islas del Atlántico Sur." For more information on this museum, and a virtual tour, please visit the official webpage: https://museomalvinas.cultura.gob.ar/ (accessed in March 2021).
} 
'Darwin Cemetery', also called the 'Argentine Military Cemetery', is the Argentine military graveyard that holds the remains of the Argentine soldiers killed in action during the war. This graveyard is located at Fish Creek, to the east of the Darwin Settlement, the location of the Battle of Goose Green. Until recently, this cemetery contained the unidentified bodies of 121 Argentine soldiers. In desperation, some family members kissed every grave, knowing one kiss at least was being given to their lost sons/husbands/brothers. In March 2018, the bodies of 90 Argentine soldiers killed in action and buried in Darwin Cemetery were identified through cutting-edge technology in DNA testing. This was made possible thanks to a campaign led by organisations formed by both British and Argentinian veterans of the Falklands War, who persuaded their respective governments to get involved in the project. DNA samples were extracted and analysed by the International Red Cross Committee with teams of forensic experts from both countries. Gravestones that until that moment read "Argentine soldier known only to God" were finally able to carry a proper name and a personal history. This identification of corpses meant that more than 200 relatives of these soldiers were able to visit the actual grave for the first time. Families were finally given the opportunity to put a name on the graves, nearly 36 years after the bitter war fought between Argentina and the United Kingdom in a violent struggle for the possession of these South Atlantic islands. The identification of these corpses would have certainly been a turning point for many Argentinian families, bringing some closure for the families of the deceased, since up to that moment there had been no specific grave by which to mourn and grieve the dead, only a graveyard. These families have suffered a double bereavement of losing a person to war and having no specific place to shed a tear or lay a flower. Besides, the identification of these bodies will presumably be helpful in the search of finding new harmonies that would ease the remaining political tension between the two nations involved in the war. The political dispute for the sovereignty of the Falkland Islands is still on/going. Nevertheless, it constitutes an example of how two former enemies doing collaborative work on humanitarian issues can bring about political reconciliation. The commemorative activities that took place in the Darwin cemetery for the identification of the bodies can also be read in gendered terms. The media has shown images of several women in tears by the recently identified tomb of the sons or husbands7.

\footnotetext{
7 Some examples with interviews and pictures of women by the graves can be found in the following newspaper articles: https://www.clarin.com/politica/conmovedores-testimonios-familiares-viajaronmalvinas-homenajear-ex-combatientes o BkvSagL5M.html (accessed March 2021); https://www.lanacion.com.ar/politica/malvinas-el-cementerio-donde-las-tumbas-al-fin-tienennombre-nid2106475/ (accessed March 2021); https://elpais.com/internacional/2018/03/26/argentina/1522078167_708033.html (accessed March 2021).
} 


\section{Conclusion}

All in all, this paper has tried to shed some light on how the dead are constructed into a narrative of national heroism and the symbolic value attached to memorial sites and collective mourning. It is important to mention that although the two nations involved in the war were so far apart and the actual war was planned from the capital cities which were many miles distant from each other, the construction of nationalisms, patriotisms and hero-worshipping were - and still are - very similar. The United Kingdom and Argentina were both experiencing trouble at home, with strikes and demonstrations, public protests and civil rights issues. By engaging in a war, both countries managed to construct a common enemy, one which gave the politicians and the press to unite and call-in specialists to create a war of propaganda also. The war fought between soldiers who swore to a flag that promised them honour and fame became empty promises when they fell in battle, whether they fought for one country or another. Death is the grand leveller of all: gender, race, ethnicity, and class. The monuments and the honours are for the living, not the dead. The women and children, the very old and the very young, are amongst those in whom the real memories survive.

\section{References}

Ashplant, Timothy G. et al (eds). The Politics of War Memory and Commemoration. London: Routledge, 2000.

Chambers, Sarah. “'Drying their Tears': Women's Petitions, National Reconciliation and Commemoration in post-Independence Chile." Gender, War and Politics. Transatlantic perspectives. 1775-1830. Ed. Karen Hagemann et al. London: Palgrave Macmillan, 2010: 343-6o.

Coker, Thomas F., and Yeung, Heather H. "Remembering Responsibly." Memory in the Twenty-First Century: New Critical Perspectives from the Arts, Humanities, and Sciences. Ed. Sebastian Groes. Hampshire and New York: Palgrave MacMillan, 2016: 292-97.

Edy, Jill A. "Journalistic Uses of Collective Memory” in Journal of Communication. Spring 1999, vol. 49, No. 2: 71-75.

Foucault, Michel, The History of Sexuality: an Introduction, Vol. I.. London: Penguin Books Ltd, 1979. Translated by Robert Hurley.

Gilbert, Catherine, Kate McLoughlin, and Niall Munro. "Introduction: The Call to Remembrance.” On Commemoration: Global Reflections upon Remembering 
War. Ed. Catherine Gilbert, Kate McLoughlin, and Niall Munro. Oxford and New York: Peter Lang, 2020: 1-10.

Halbwachs, Maurice. On Collective Memory, edited and translated by Lewis A. Coser. Chicago: Chicago University Press, 1999 [1950].

Hobsbawm, Eric and Terence Ranger. The Invention of Tradition. Cambridge: CUP, 1983.

King, Nicola. Memory, Narrative, Identity. Remembering the Self. Edinburgh: Edinburgh University Press, 2000.

Lloyd, Genevieve. "Selfhood, War and Masculinity." Feminist Challenges: Social and Political Theory. Ed. Carole Pateman and Elizabeth Gross. Boston: Northeastern University Press, 1987: 63-77.

Munro, Niall. "Introduction: More than a Stone - Finding ourselves in our Monuments." On Commemoration: Global Reflections upon Remembering War. Ed. Catherine Gilbert, Kate McLoughlin, and Niall Munro. Oxford and New York: Peter Lang, 2020: 113-121.

Musil, Robert. Monuments. Posthumous Papers of a Living AuthorNew York: Archipelago Books, 2006. Translated by Peter Worstman.

Noakes, Lucy. "Mass-Observation, Gender and Nationhood: Britain in the Falklands War." The Mass-Observation Archive Occasional Paper No. 5, University of Sussex Library, 1996.

---. War and the British. Gender and National Identity, 1939-91. London and New York: I.B. Tauris Publishers, 1998.

Nora, Pierre. "Between Memory and History: Les Lieux de Mémoire." Representations, 26 (1989): 7-25.

Milmo, Cahal. "Falklands referendum: David Cameron calls on Argentina to respect the wishes of islanders after 99.8 per cent vote to stay British." Independent, 12 March 2013: http://www.independent.co.uk/news/world/americas/falklandsreferendum-david-cameron-calls-on-argentina-to-respect-the-wishes-ofislanders-after-998-per-cent-vote-to-stay-british8529669.html?origin=internalSearch (accessed March 2021).

Misztal, Barbara A. Theories of Social Remembering. Maidenhead and Philadelphia: Open University Press, 2003. 
Newton-Dunn, Tom. “'I was one of the lucky ones'." Sun, 4 Oct. 2007. Online edition: http://www.thesun.co.uk/sol/homepage/news/article231207.ece (accessed February 2021).

Piehler, Kurt. "The war dead and the gold star: American commemoration of the First World War." Commemorations: The Politics of National Identities. Ed. John Gillis. Princeton University Press, 1994: 169- 85.

Rees, Alun. "Revealed at last: face of Falklands 'yomping' Marine.” Daily Mail, 21 Apr. 2007. Online edition: http://www.dailymail.co.uk/news/article449891/Revealed-face-Falklands-yomping-Marine.html (accessed February 2021).

Volkan, Vamik. "Not letting go: from individual perennial mourners to societies with entitlement ideologies.” On Freud's Mourning and Melancholia. Ed. Leticia Glocer Fiorini et al. London: International Psychoanalytical Association: 2007: 90-109.

Wasson, Sara. Urban Gothic of the Second World War: Dark London. London: Palgrave Macmillan, 2010.

Winter, Jay. Remembering War. New Haven \& London: Yale University Press, 2006. 